\title{
TMSB4Y Gene
}

National Cancer Institute

\section{Source}

National Cancer Institute. TMSB4Y Gene. NCI Thesaurus. Code C137961.

This gene is involved in the downregulation of actin polymerization. 